\title{
EMISSION OF FINE PARTICLES (PM2.5) FROM RESIDENTIAL BIOMASS COMBUSTION IN CROATIA AND HOW TO REDUCE IT
}

\author{
Mirela Poljanac ${ }^{*}$ \\ ${ }^{1}$ EKONERG Ltd., Koranska 5, 10000 Zagreb, Croatia \\ *E-mail of corresponding author: mirela.poljanac@ekonerg.hr
}

\begin{abstract}
Wood burning in residential appliances is very represented in the Republic of Croatia. It is a main or an additional form of heating for many households in rural and urban areas and is therefore an important source of air pollution. The choice of energy and the combustion appliance used in home have a significant impact on PM2.5 emissions. The paper informs the reader about PM2.5 emissions, their main sources and impacts on human health, environment, climate, air quality, and the reason why PM 2.5 emissions from residential wood burning are harmful. Paper also gives an overview of spatial PM2.5 emission distribution in Croatia, their five air quality zones and four agglomerations. The paper analyses the sources and their contribution to PM2.5 emissions with the relevance of PM 2.5 emissions from residential plants, the use of fuels in residential plants and their contribution to PM2.5 emissions and PM2.5 emissions by fuel combustion technologies in residential sector. Appropriate strategies, policies, and actions to reduce the impact of residential biomass (wood) burning on the environment, air quality and human health are considered.
\end{abstract}

Keywords: air pollution, spatial emission distribution, combustion impact, environmental protection strategy, air quality zones

\begin{tabular}{c}
\hline Received: 27.4.2020. / Accepted: 1.6.2020. \\
Published online: 7.12.2020. \\
\hline Review paper \\
https://doi.org/10.37023/ee.7.2.6
\end{tabular}

\section{INTRODUCTION}

In the Republic of Croatia, the wood consumption in residential sector is a main source of energy use for space heating, cooking, and water heating. Therefore, the residential biomass combustion is estimated as a key source of fine particles $\left(\mathrm{PM}_{2.5}\right)$ emissions in Croatia (Ministry of Environment and Energy 2019). This paper considers primary particulate matter emissions data from the anthropogenic sources. For performed analysis, the main source of data is Croatian national emission inventory. The biomass (fuelwood) is a renewable source of energy that has advantage regarding climate (European Biomass Industry Association 2019). In theory, the combustion of biomass considers a sustainable $\mathrm{CO}_{2}$ neutral source of energy (European Commission 2003; IPPC 2006). In reality, the carbon dioxide is emitted when burning wood but it the fact is that this carbon was taken up by the tree from the air during its growing and this part of the emissions is considering as carbon-neutral (Leturcq 2014; World Bioenergy Association 2012).

Burning wood at home appliances is in generally under non-optimal operating conditions (e.g. with low efficiency fireplaces and stoves, poor fuel quality, bad burn practises, lacking proper maintenance of fireplaces and stoves) which results with significant emissions of air pollutants and particularly $\mathrm{PM}_{2.5}$. The combustion of the fuel wood in small appliances is incomplete which result with many times greater emissions that in bigger plants (European Environment Agency 2016).

Rising energy prices of natural gas and electricity, and in some extend, poor financial situation of many Croatian citizens leads to the bigger use of biomass as a residential fuel. This result in negative impacts on air quality, human health, environment, climate, and visibility. To minimize the negative impact of fuelwood combustion in residential sector and to reduce the $\mathrm{PM}_{2.5}$ emissions joint actions on global, national, regional, local, and home level are required.

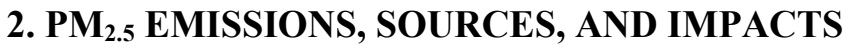

Particulate matter (PM) is a widespread air pollutant, consisting of a mixture of solid and liquid particles suspended in the air. The mass concentration of particles with a diameter of less than $10 \mu \mathrm{m}\left(\mathrm{PM}_{10}\right)$ and particles with diameter less than $2.5 \mu \mathrm{m}\left(\mathrm{PM}_{2.5}\right)$ is commonly used indicator for describing PM that are relevant to health (World Health organization 2013).

Emissions of $\mathrm{PM}_{2.5}$ originate from a variety of anthropogenic i.e. made by human and natural activities and may be directly emitted ("primary PM") or formed in the atmosphere ("secondary PM"). Primary emissions of PM can exist as solid or liquid matter (the "filterable" portion) or as gases (the "condensable" portion). The sources 
of primary anthropogenic $\mathrm{PM}_{2.5}$ emissions (see figure 1) may be point, area, line, and fugitive ones. Activities from which are primary anthropogenic $\mathrm{PM}_{2.5}$ emissions originate include wood (biomass) and fossil fuel combustion, building construction and demolition, quarrying and mining, vehicle tyre and break wear, road abrasion, and agricultural activities. Natural sources such as forest fires and volcanos may have local and global impact on environment, climate, air quality and human health in respect of PM pollution. Secondary PM formed by physical and chemical reactions from other pollutants ( $\mathrm{SOx}, \mathrm{NOx}, \mathrm{VOCs}, \mathrm{NH}_{3}$ ) called precursors. Secondary PM can be formed at locations distant from the sources that release the precursor gases.

Impacts of $\mathrm{PM}_{2.5}$ emissions are various. The particle pollution can causes adverse health effects like: coughing or difficulty breathing, increase the risk of asthma attack, heart attack, decreased lung function, causes premature death and decreasing the air quality (outdoor and indoor) (American Lung Association 2019, Doctors and Scientists Against Wood Smoke Pollution 2019, World Health Organisation 2018).

It has negative impact on the climate in many ways: wood smoke (PM) absorbs sunlight, impacts on cloud formation and precipitation as well as deposition on ice surfaces. As particles from wood burning are transported over large distances, they also harm sensitive ecosystems, such as the arctic that are far away from the initial sources of pollution (Deutsche Umwelthilfe 2016).

Fine particles $\left(\mathrm{PM}_{2.5}\right)$ are the main cause a deterioration of visibility, environmental damage, and damage of materials (United States Environmental Protection Agency 2018). Environmental damage with PM manifests as ecosystem degradation, depleting the nutrients in soil, damaging sensitive forests, damaging farm crops, affecting diversity of ecosystems, contributing to acid rain effects, and affecting animal health and productivity. Deposition of PM causes damage of materials like stain and damage of stone and other materials, like culturally and historically important objects such as statues, monuments, and buildings.

Figure 1 shows various sources of $\mathrm{PM}_{2.5}$ emissions and their multiple impacts i.e. adverse effects.

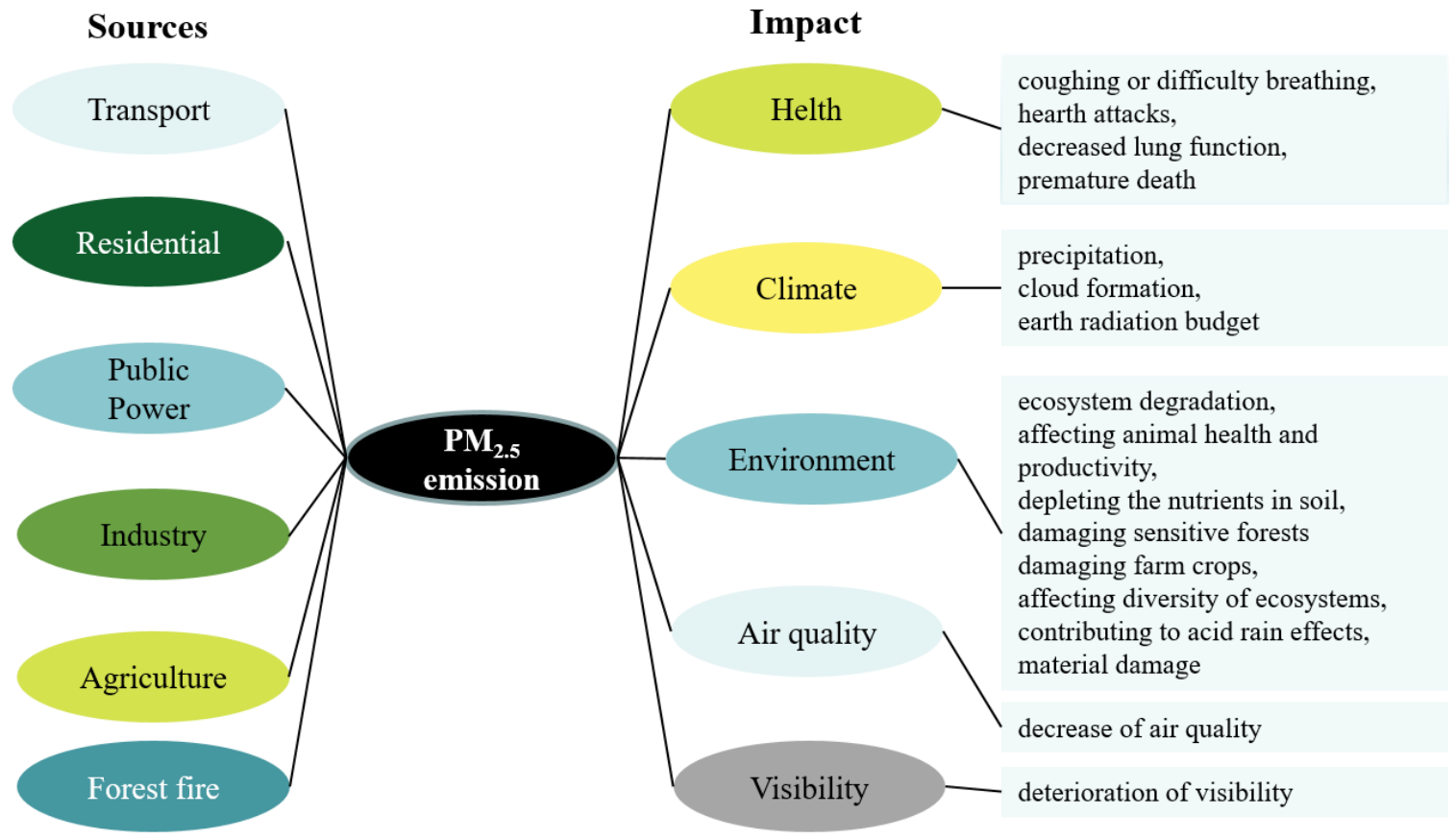

Figure 1. Sources and impacts of $P M_{2.5}$ emissions

Biomass (wood) burn is considered to have neutral impact on $\mathrm{CO}_{2}$ emissions (carbon neutral) and on the other hand is a cause of air pollution in urban and rural areas (Figure 2). Carbon neutral theory for wood burning (World Bioenergy Association 2012) stems from theory that trees assimilate the same amount of $\mathrm{CO}_{2}$ throughout their lifetime as the amount released when burning the wood at home. However, even if the wood burning is considered as the carbon neutral, the truth is that it is not climate neutral if biomass is used not sustainably and that there are reasons for be concern about the fact that wood is widely used energy in residential sector. 


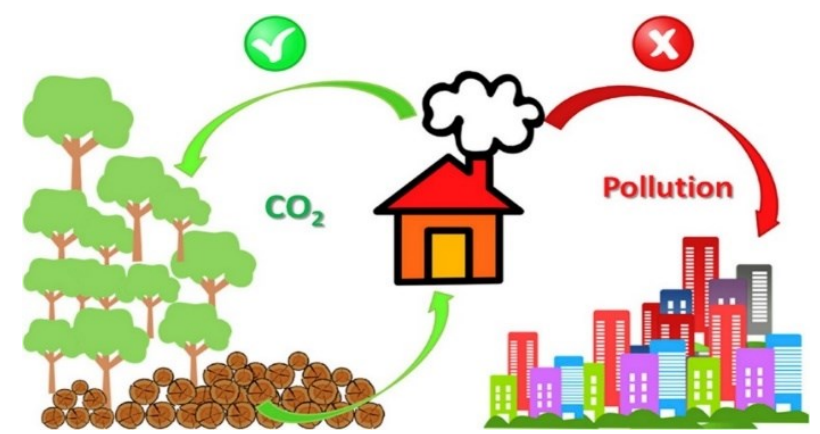

Figure 2. Impact of biomass (wood) burn on $\mathrm{CO}_{2}$ and air pollutants emissions (Cincinelli et al. 2019)

Reasons for being concern about residential wood combustion are the impact on ambient air pollution and health, the climate policy, and economic hardship that usually leading to fuel switching. Its negative impact on ambient air pollution and health can be found in many studies (e.g. Caseiro et al. 2009; Chen et al. 2012; Crilley et al. 2015; Hellen et al. 2008; Herich et al. 2014; Naeher et al. 2007; Pascal et al. 2013; Saarikoski et al. 2008; Saarnio et al. 2012).

Exceedances of the EU's air quality limit values are still one of the major environmental problem in EU. For 2015 up to $8 \%$ of the urban population was exposed to concentrations above the EU limit value of $25 \mu \mathrm{g} / \mathrm{m}^{3}$ for fine particulate matter $\left(\mathrm{PM}_{2.5}\right)$, and more than $82 \%$ to levels above the much stricter WHO guideline value of 10 $\mu \mathrm{g} / \mathrm{m}^{3}$ (European Commission 2019).

According to Chafe (2015) combustion of wood in residential areas and often under cold, calm meteorological conditions can lead to high exposure compared to other pollution sources, owing to the principle of intake fraction (the proportion of a released material that is inhaled by humans) (Figure 3).

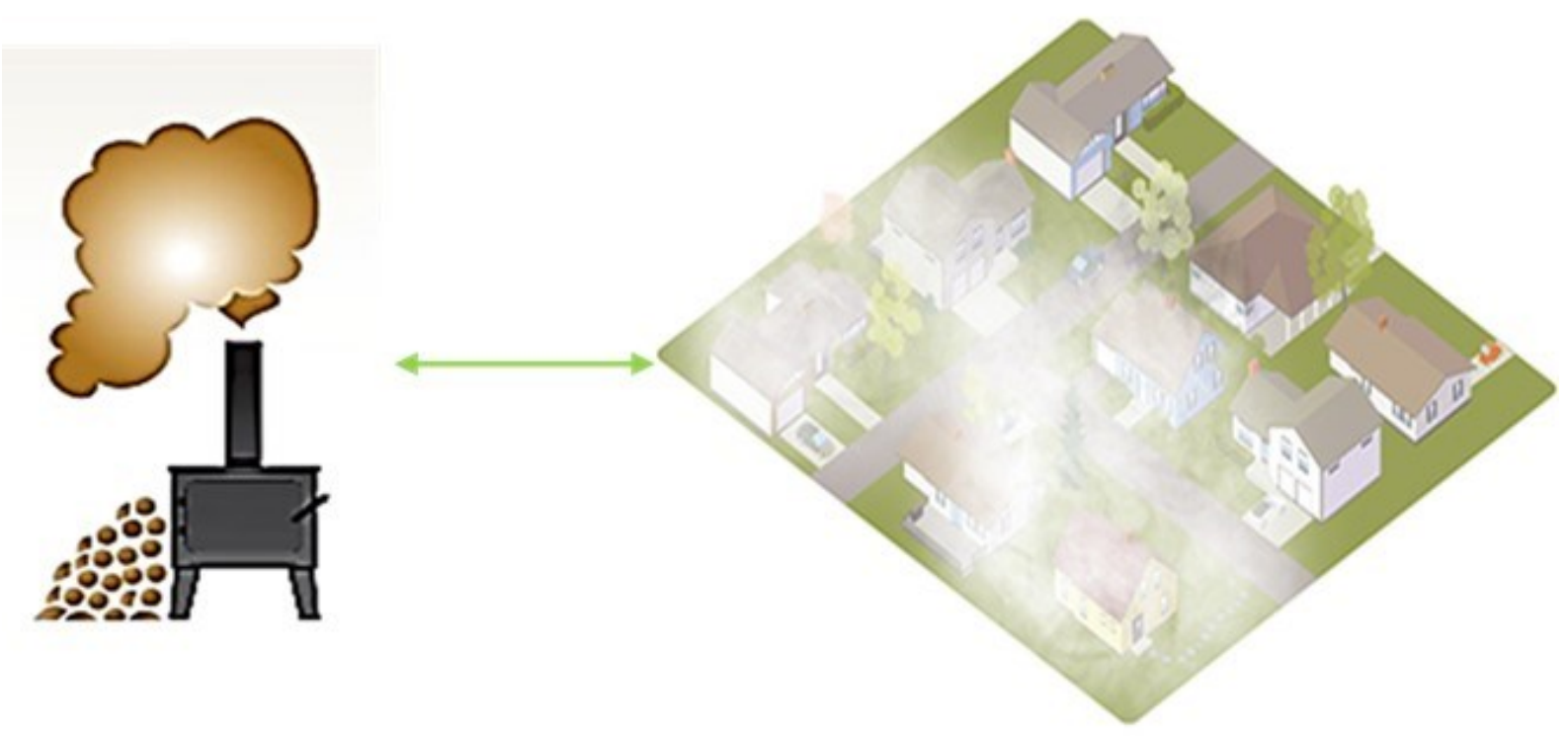

Figure 3. Residential biomass (wood) combustion as source of fine particle pollution (Doctors and Scientists Against Wood Smoke Pollution 2019)

Burning wood in homes produces more neighbourhood-level particulate matter pollution than using electricity, natural gas, or liquid fuels for heating, and effecting on ambient air quality (Chafe 2015). WHO also reported that, in 2012, 3.7 million premature deaths occurred due to exposure to outdoor (ambient) particulate air pollution, including 482,000 in Europe and 94,000 in Canada and the United States, and that residential wood combustion is a contributor to mentioned outdoor air pollution (World Health Organisation 2014).

The reason why PM pollution from burning wood in homes is harmful for humans lay down at the fact that fine particles $\left(\mathrm{PM}_{2.5}\right)$ have a small diameter and are able to inhale by humans and income deeply into the respiratory tract, reaching the lungs, blood and can get embedded in organs (Figure 4). 


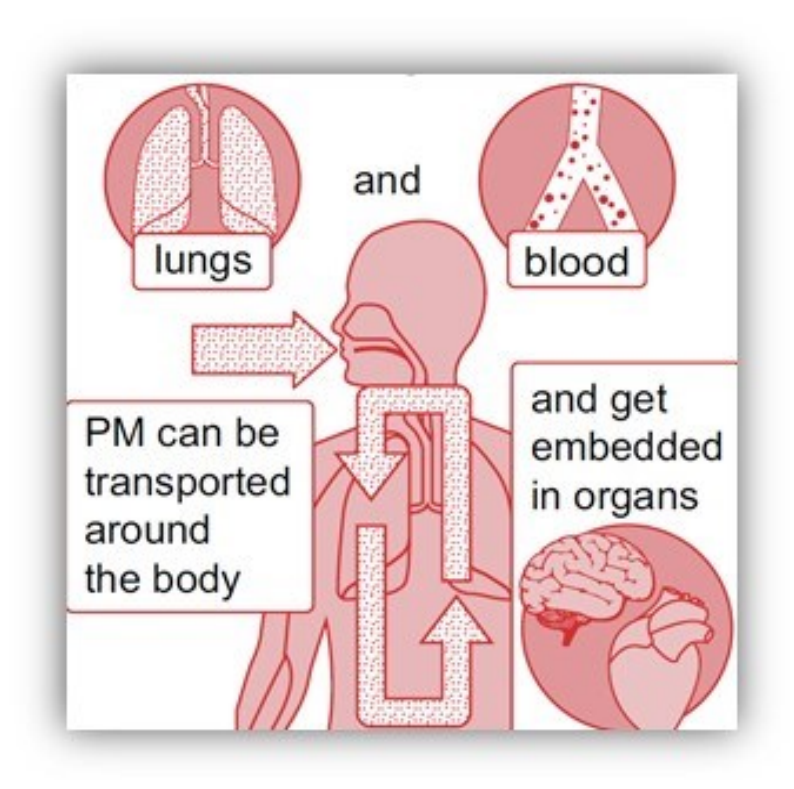

Figure 4. Impact of fine particles $P M_{2.5}$ when inhaled by humans (Department for Environment, Food \& Rural Affairs 2019)

Another reason for concern comes from the climate and energy policies. Biomass fuels were included in the European Commission's strategy for reaching the "20-20-20" targets (20\% reduction in greenhouse gas emissions, $20 \%$ of final energy consumption from renewable energy and $20 \%$ increase in energy efficiency by 2020 ) (European Commission 2010). However, it has been evidenced that climate-oriented policies may not always work in line with air quality-oriented policies, and vice-versa. Residential heating with wood is encouraging in many European countries and touted as a renewable fuel that can assist with climate change mitigation, contribute to energy security, and contribute to the alleviation of energy poverty (e.g. International Energy Agency 2013, Kyprianou et al. 2019, Levander \& Bodin 2014, Ofgem 2014). Due to government incentives and subsidies, the increasing costs of other energy sources and the public perception that it is a "green" option, the presence of residential wood combustion is still high and rising in some countries (Chafe 2015).

Poor economic situation, energy poverty and affordability that consequently leads to fuel switching in homes from e.g. natural gas to fuel wood, wood waste or from electricity to fossil fuels or fuel wood is also reason for concern (Saffari et al. 2013).

Burning conditions of residential wood combustion are often inefficient due to incomplete combustion and there are often no household-level emissions controls for PM or regulations as is the case with emissions from transport, industry and power plants that are already controlled or legislation is in place to their reduction. Therefore, wood stoves even that with eco designed emit more fine particulates $\left(\mathrm{PM}_{2.5}\right)$ than most diesel vehicles. Figure 5 shows comparison of estimated PM emission rates from a $5 \mathrm{~kW}$ stove $(\mathrm{g} / \mathrm{h})$ compared to typical exhaust PM emissions $(\mathrm{g} / \mathrm{h})$ from different Euro standards diesel road vehicles based on emissions limits (Air Quality Expert Group (UK) 2017). According to comparison made by (Air Quality Expert Group (UK) 2017), it can be concluded that one conventional wood fired stove emits PM like 40 diesel passenger cars (EURO 5/6) and approximately 13 new heavy duty vehicles (Euro IV) (Figure 5). They also find out that one eco-designed wood fired stove will reduces PM emissions by $54 \%$ comparing to conventional wood fired stove and in the same time that this eco-designed wood fired stove emits PM like 18 diesel passenger cars (EURO 5/6). 


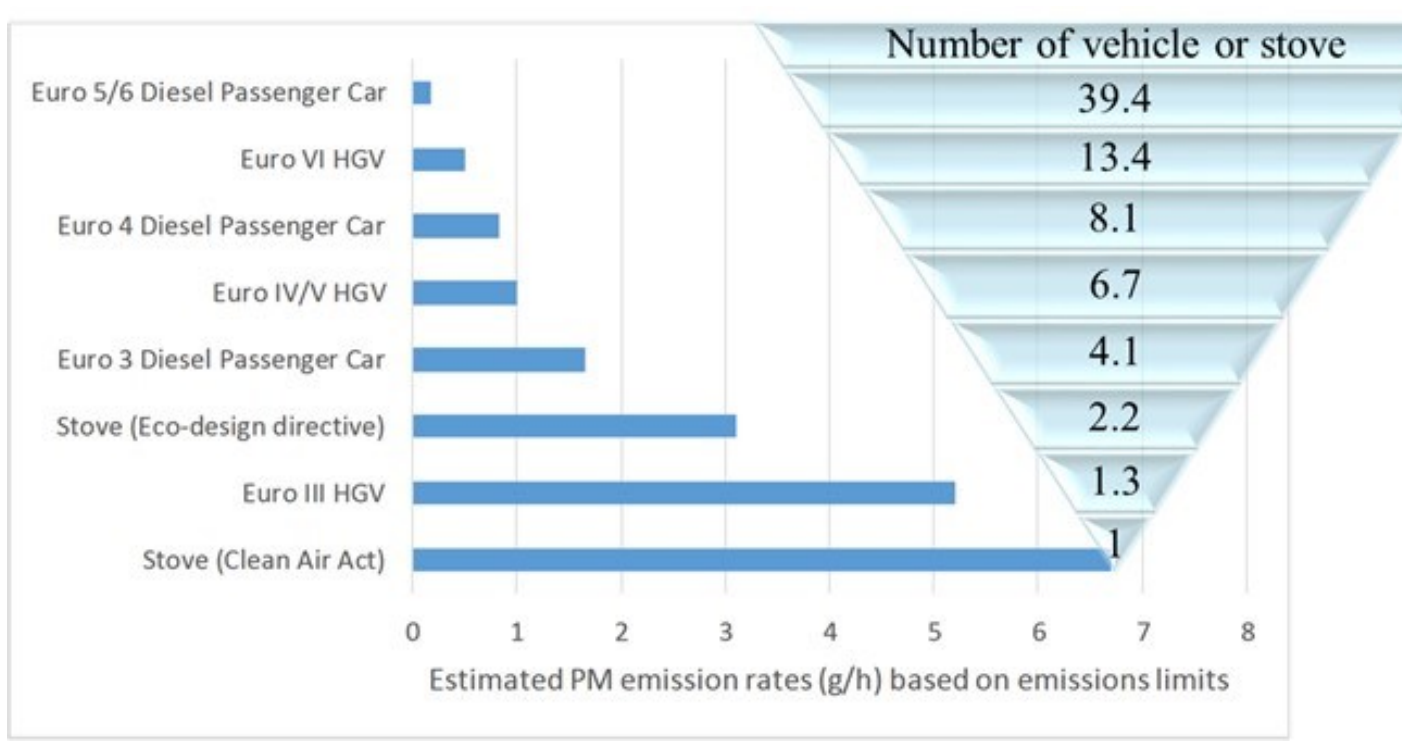

Figure 5. PM emissions from $5 \mathrm{~kW}$ wood stove $(\mathrm{g} / \mathrm{h})$ compared to exhaust PM emissions $(\mathrm{g} / \mathrm{h})$ from diesel vehicles (Air Quality Expert Group (UK) 2017)

\section{USE OF BIOMASS (WOOD) IN RESIDENTIAL COMBUSTION AS A SOURCE OF AIR

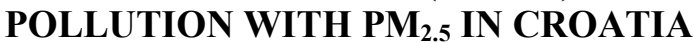

The source that is contributing most to $\mathrm{PM}_{2.5}$ emissions in Croatia, is a Small combustion (Figure 6). Within the Small combustion installations activities that are considered to have a thermal capacity $\leq 50 \mathrm{MW}_{\text {th }}$, a Residential sector has a domination regarding $\mathrm{PM}_{2.5}$ emissions in Croatia during the history and nowadays (Figure 7). In 1990, the Small combustion was responsible for $75 \%$ of $\mathrm{PM}_{2.5}$ emissions in Croatia. The Industry represented only $10 \%$, and all other sources $15 \%$ of $\mathrm{PM}_{2.5}$ emissions in Croatia in 1990. The Off-road transport and Road transport were responsible for $5 \%$ and $3 \%$ of total $\mathrm{PM}_{2.5}$ emissions in Croatia in 1990. There has been little change over 27 years, so in 2017, the Small combustion was responsible for $68 \%$ of total $\mathrm{PM}_{2.5}$ emissions, while the Road transport accounted for $9 \%$ (that is an increasement of approx. $13 \%$ ) and Industry $8 \%$ (that is a decrease of approx. $64 \%$ ) in Croatia.

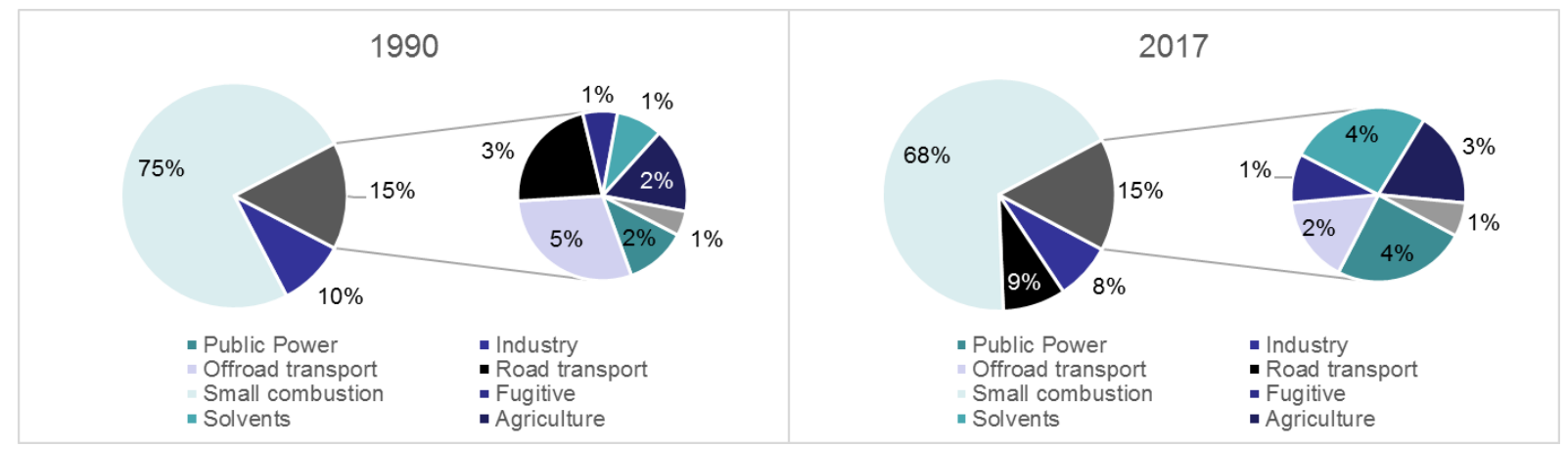

Figure 6. Emissions of $P M_{2.5}$ in Croatia, 1990 and 2017

(CEIP - EMEP Inventory files NFR for Croatia 2019)
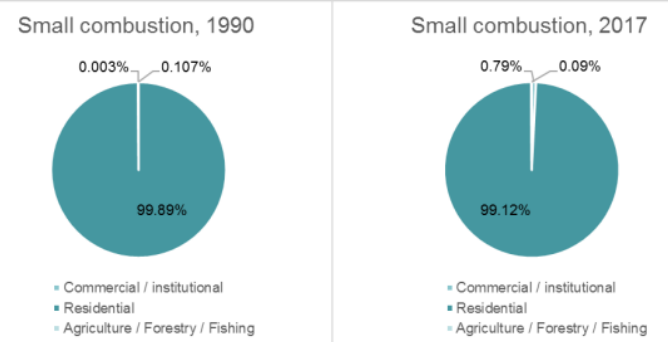

Figure 7. Relevance of residential plants on PM 2.5 emissions in Croatia, 1990 and 2017

(CEIP - EMEP Inventory files NFR for Croatia 2019) 
In the Republic of Croatia, there is a biomass (wood) domination in residential stationary fuel consumption both now and in the 90's. Since 1990 a total energy consumption in residential sector in 2017 has increased by 2 $\%$. The use of solid fuels (coal) and liquid fuels have decreased by $97 \%$ and $63 \%$ respectively in the observed period, while the use of natural gas and biomass have increased by $144 \%$ (approx. by 2.44 times) and $8 \%$ respectively (Figure 8).

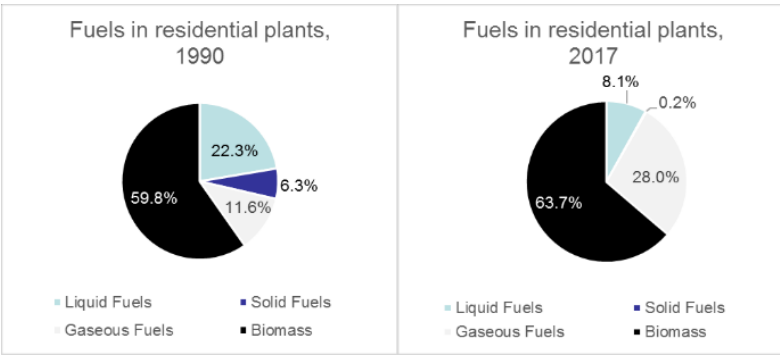

Figure 8. Fuel consumption (PJ) in residential plants in Croatia, 1990 and 2017

(CEIP - EMEP Inventory files NFR for Croatia 2019)

In residential sector a variety of fuel combustion technologies are applied. Emissions of $\mathrm{PM}_{2.5}$ from residential combustion appliances are function of fuel combustion technology type and fuel type (Figure 9) but as well of fuel quality, operational practices, and maintenance. Figure 9 shows that the most polluting appliance is open fire fireplaces burning wood, following by wood fired conventional stoves. The less polluting residential combustion appliances in respect of $\mathrm{PM}_{2.5}$ emissions are gas fired boilers, following by liquid fired boilers, fireplaces on natural gas and pellet stoves. By comparison of $\mathrm{PM}_{2.5}$ emissions characteristic for each residential heating appliance type provided by EMEP/EEA Guidebook 2016 (European Environment Agency 2016), it can be stated that that the $\mathrm{PM}_{2.5}$ emissions from one open fire fireplace are equivalent to the emissions of approximately 4100 natural gas fired boilers, 28 pellet stoves or 9 modern advanced/ecolabelled stoves/boilers burning wood. From the above it follows that significant air quality benefits can be expected by changing fuel from wood to natural gas or by replacement of an old conventional stove with new efficient appliance or modern pallet system.

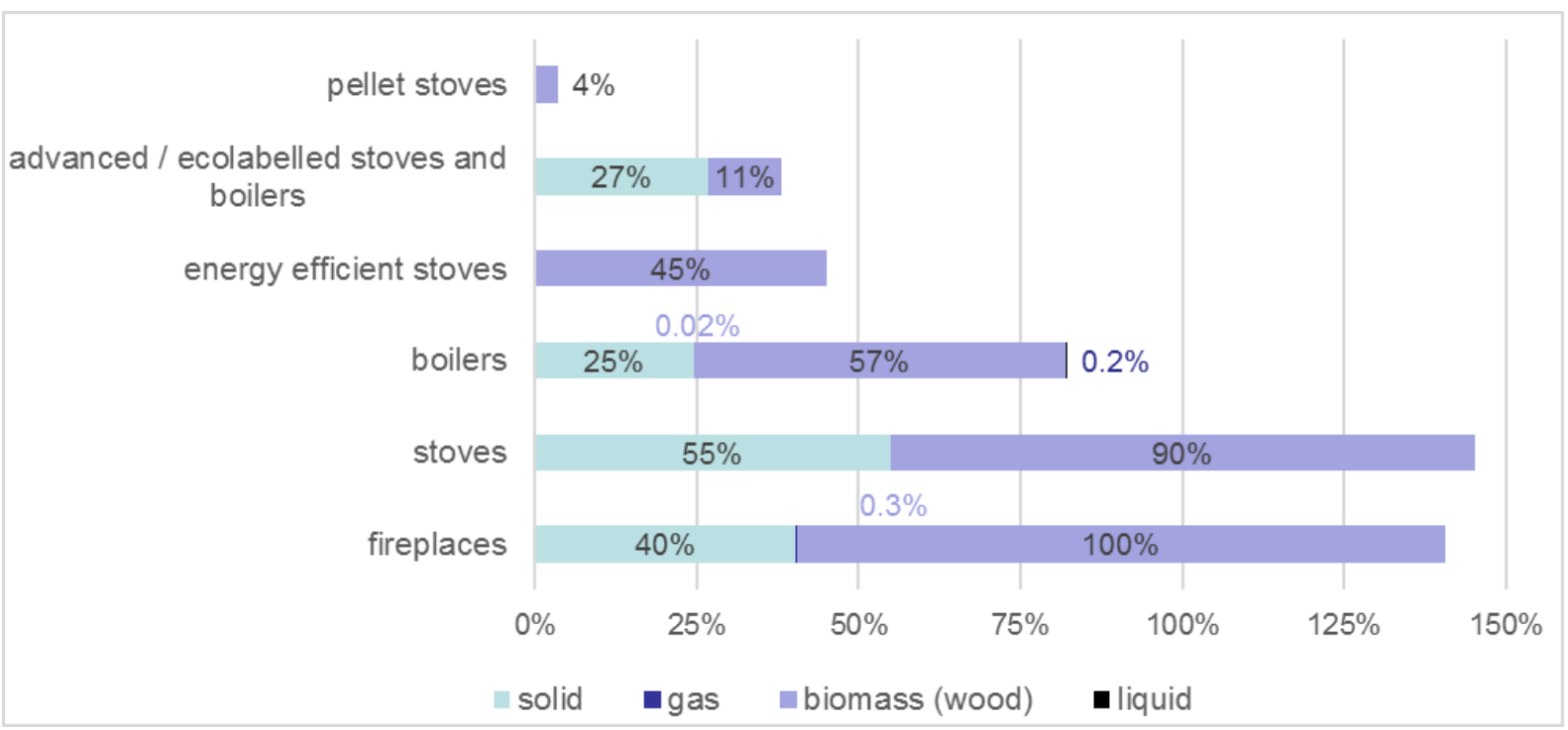

Figure 9. Relative PM 2.5 emissions by type of residential plants $(100 \%=820 \mathrm{~g} / \mathrm{GJ})$

(European Environment Agency 2016)

\section{SPATIAL DISTRIBUTION OF PM 2.5 EMISSIONS IN CROATIA}

EKONERG Ltd. has developed a model to distribute emissions from the national emission inventories on an EMEP grid, resolution $0.1^{\circ} \times 0.1^{\circ}$ (longitude, latitude) in a geographic coordinate system (WGS84) $\approx 7 \mathrm{~km} \times 7$ $\mathrm{km}$. The model is covering the Croatian land and sea territory along with Croatian 5 Air quality zones and on an EMEP grid, resolution $0.5 \mathrm{~km} \times 0.5 \mathrm{~km}$ (longitude, latitude) covering the Croatian 4 agglomerations. Zones and agglomerations were set according to the Regulation determining zones and agglomerations according to levels of air pollution on Croatian territory (Official Gazette 1/2014-24). The new spatial high-resolution distribution model for emissions to air (EKOREGIS) has been developed according to the requirements for reporting of gridded 
emissions to the EMEP/EEA guidance. The results of this model are spatial emissions data that are an input for the air quality modelling, which is an input for assessment of atmospheric concentrations and deposition. The results of model assessments inform national and international policies used to improve the environment and human health (Official Gazette 1/2014-24). EKOREGIS is developed to generate improved quality of spatial emission data for use in air quality modelling in assessing the existing air quality situation, air quality forecasting, air quality planning, source apportionment and air pollution exposure studies. EKOREGIS includes emission distributions for each of NFR and SNAP source category in the Croatian inventory system: stationary combustion, mobile sources, fugitive emissions, industrial processes and product use, agriculture, waste, forest fires. The results of the model EKOREGIS are available at: https://emep.haop.hr/.

In Croatia there are three main climatic regions continental, central (mountain) and costal (maritime). These three climatic regions are conditioned with an extremely varied relief with three main types: lowland Pannonian, mountainous Dinaric and coastal Adriatic. The central part of Croatia is the coolest one with the mountain climate and the continental part is with the continental climate that is slightly milder than in the central part. The coastal part of Croatia has mild Mediterranean climate. The last digital Köppen-Geiger climate classification at an unprecedented 1-km resolution for the present-day (1980-2016) (Beck et al. 2018) for Croatia is available at https://commons.wikimedia.org/wiki/File:Koppen-Geiger_Map_HRV_present.sv. This climatic classification was used as one of variables for spatial distribution of $\mathrm{PM}_{2.5}$ emissions at the Croatian territory. It can be seen that emissions of $\mathrm{PM}_{2.5}$ are not equally distributed on the territory of the Republic of Croatia (Figure 10). Areas where the most of national $\mathrm{PM}_{2.5}$ emissions are allocated, are at the continental and central part of Croatia, and at the most populated urban areas - big cities. The coastal part of Croatia is the area where the less of $\mathrm{PM}_{2.5}$ emissions are allocated, with exception of the big cities.

Figure 11 shows $\mathrm{PM}_{2.5}$ gridded emissions by 5 Croatian air quality zones. These maps cover the total national $\mathrm{PM}_{2.5}$ emissions without $\mathrm{PM}_{2.5}$ emissions for four agglomerations.

Figure 12 shows $\mathrm{PM}_{2.5}$ gridded emissions by four Croatian agglomerations in resolution $0.5 \mathrm{~km} \times 0.5 \mathrm{~km}$ (longitude, latitude) created at the base of EMEP grid.

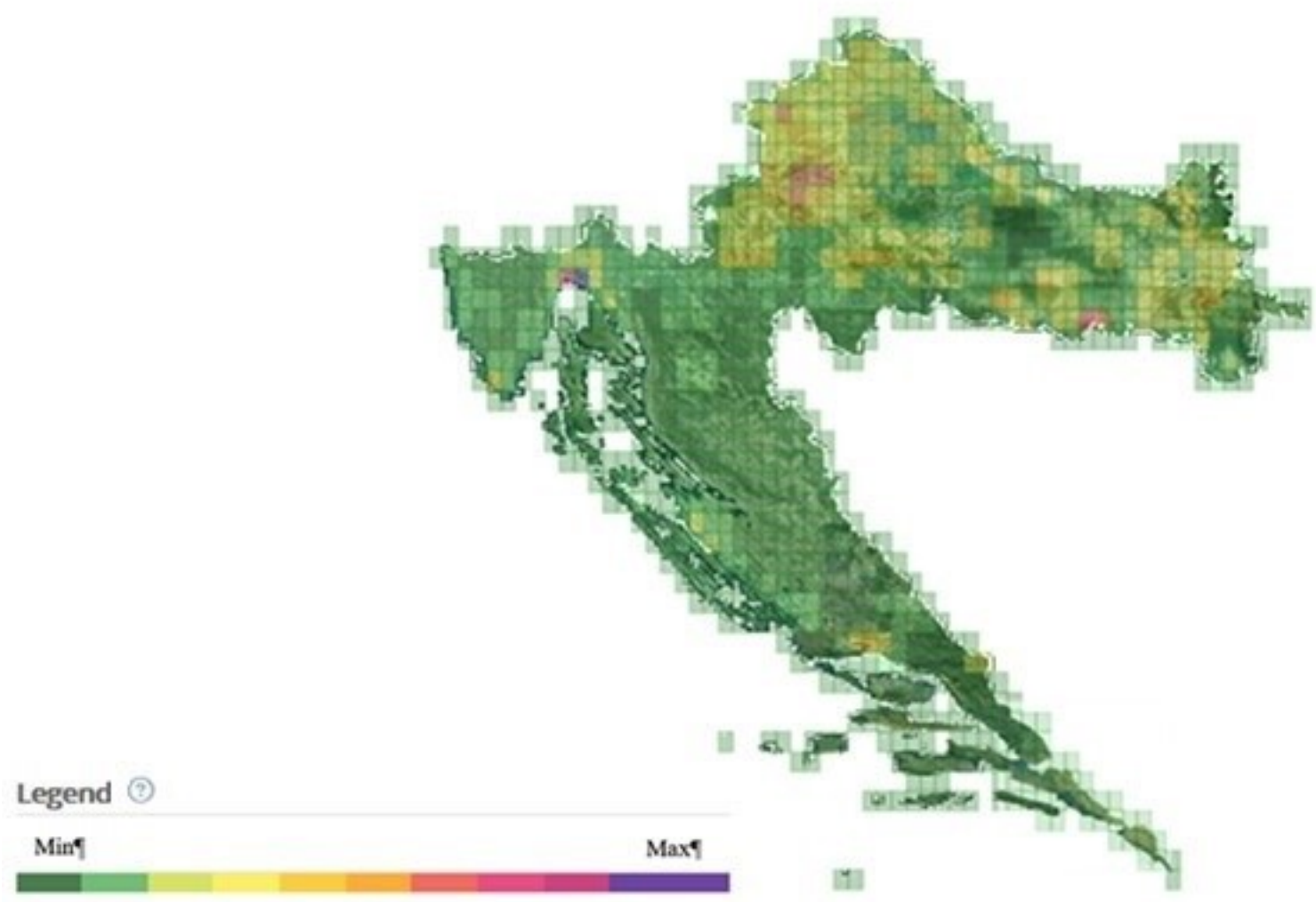

Figure 10. Spatial distribution of $P M_{2.5}$ emissions in Croatia, 2015 (Ministry of Environment and Energy 2018) 


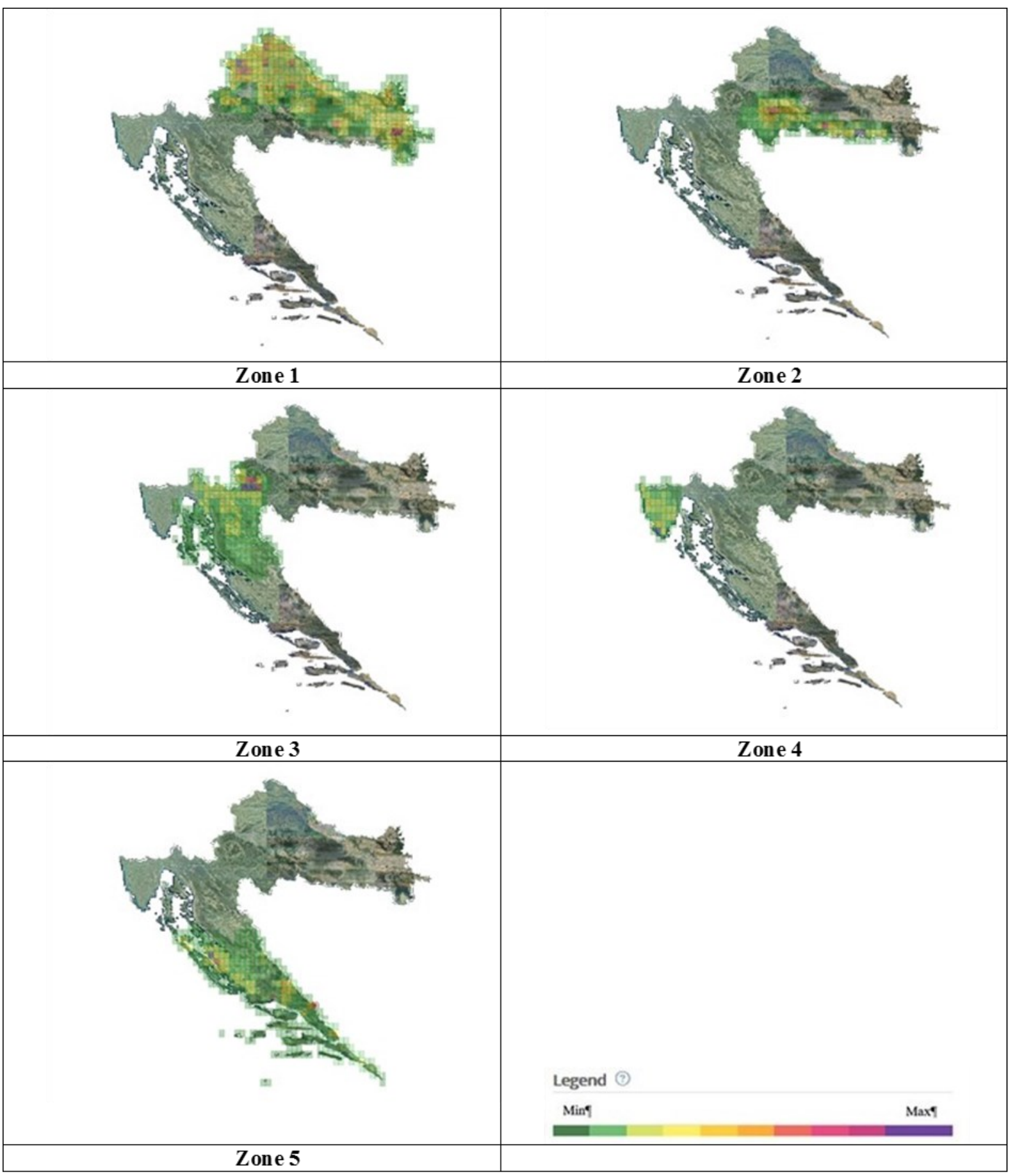

Figure 11. Spatial distribution of PM 2.5 emissions in Croatia by air quality zones, 2015 (Ministry of Environment and Energy 2018) 


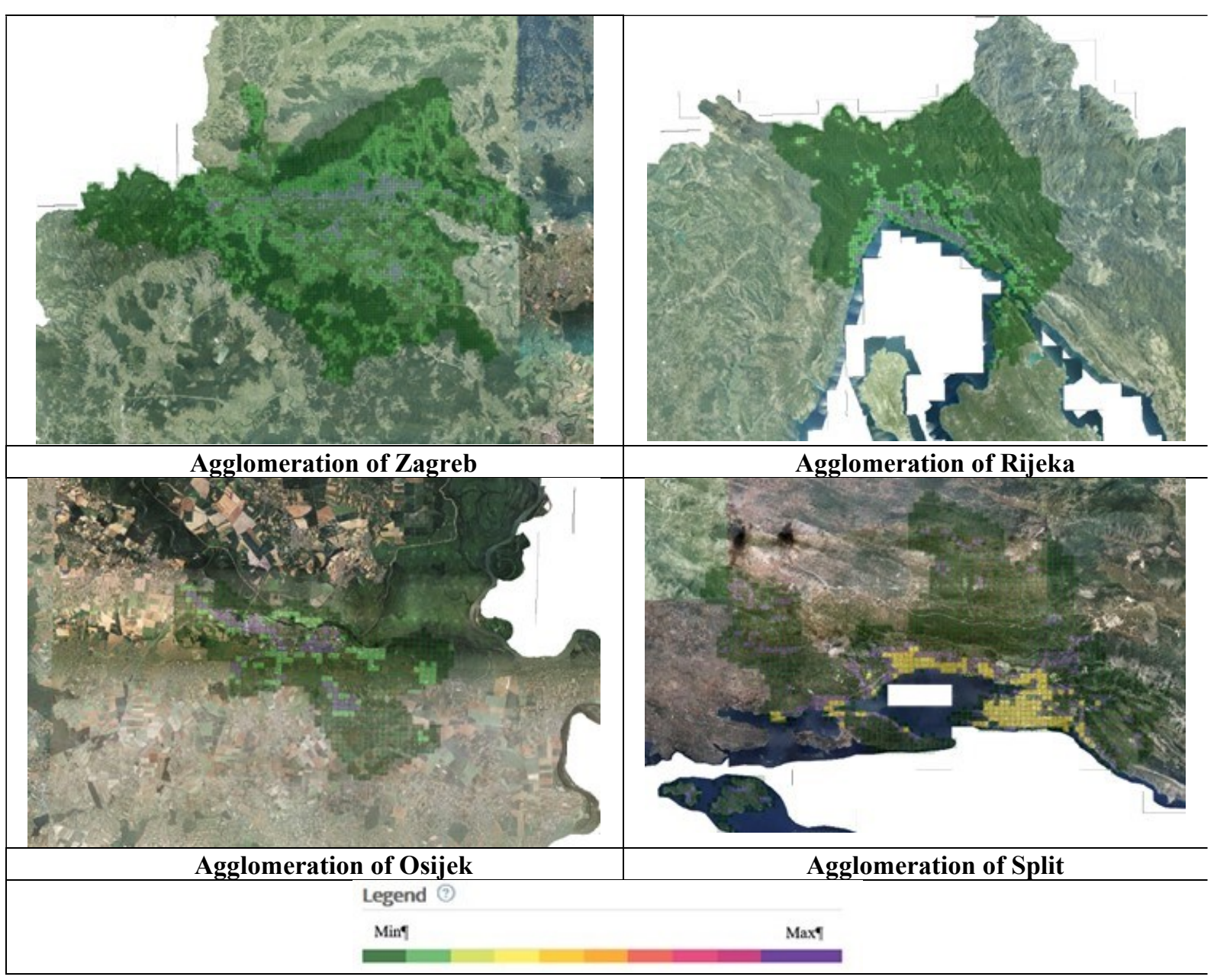

Figure 12. Spatial distribution of $P M_{2.5}$ emissions in Croatia by agglomerations, 2015 (Ministry of Environment and Energy 2018)

\section{HOW CAN PM2.5 EMISSIONS FROM RESIDENTIAL WOOD STOVES BE REDUCED}

For $\mathrm{PM}_{2.5}$ emissions reduction from residential wood stoves requires joint actions on global, national, regional, local and home level.

Global actions are taking on EU level trough the National Emission Ceilings Directive (NEC Directive) (Directive (EU) 2016/2284) and Ecodesign Directive (Directive 2009/125/EC). NEC Directive establishes the emission reduction commitments for the Member States' certain anthropogenic atmospheric emissions including fine particulate matter $\left(\mathrm{PM}_{2.5}\right)$. Ecodesign Directive establishing a framework for the setting of ecodesign requirements for energy-related products is implemented with two Regulations that define ecodesign requirements on solid fuel stoves (Commission Regulation 2015/1185) and boilers (Commission Regulation 2015/1189). Ecodesign requirements will enter into force in 2020 for boilers and in 2022 for solid fuel local space heaters that will also assist in tackling emissions of PM. Ecodesign requirements are defined for seasonal space heating energy efficiency and for emissions of particulate matter (PM), organic gaseous compounds (OGCs), carbon monoxide (CO) and nitrogen oxides (NOx).

National/regional/local policy and actions that can reduce the impact of $\mathrm{PM}_{2.5}$ emissions from domestic wood burning are addressed to fuel switching, technology exchange and educational efforts addressing burning practice. National/regional/local authority can support fuel switching from wood to cleaner fuels (e.g. natural gas or electricity), support replacement of old stoves with new ones with eco-labels or high efficiency, support pellet systems, introducing of district heating and public education programs. Objectives of educational campaigns and programmes can be addressed to promote responsible wood burning appliances but without encouraging of more wood burning, educate wood burning users on what and how they burn and on haw is that connect with the impact on their health and environment, promote energy efficiency and savings.

Home individual actions are harmonized with national, regional, and/or local policy and actions. Using cleaner energy (e.g. gas, electricity), replacing of old wood stove with ecodesigned and efficient new one or replacing it with pallets system, regularly maintaining the heating appliance and chimney by a competent person and personal education on wise burning wood, will all contribute to $\mathrm{PM}_{2.5}$ emission reductions, improve local air quality regarding $\mathrm{PM}_{2.5}$ concentrations and minimize its negative impact on health. 


\section{CONCLUSION}

Residential combustion of biomass (wood) is major source of fine particulate matter $\mathrm{PM}_{2.5}$ emissions in Croatia. For $\mathrm{PM}_{2.5}$ emission reduction from residential biomass (wood) stoves requires joint action by decision makers and residents. To protect health and environment, there is a need for policymakers in areas that have relatively high levels of outdoor air pollution from household heating-related combustion to provide incentives to switch from biomass to gas- or electricity-based for heating or to provide incentives for replacement of old stoves on wood with new ones with lower $\mathrm{PM}_{2.5}$ emissions (EC).

When assessing the environmental impact of the operation (e.g. road construction, construction of transport facilities, construction of buildings, etc.) in areas with poor air quality with respect to $\mathrm{PM}_{2.5}$, measures should be consider to prevent additional ambient air pollution with $\mathrm{PM}_{2.5}$.

\section{REFERENCES}

Air Quality Expert Group (UK) (2017) Potential Air Quality Impacts from Biomass Combustion. Data from Table 5

American Lung Association (2019) American Lung Association "State of the Air 2019", Chicago p.39-41

Beck H, Zimmermann N, McVicar T et al. (2018) Present and future Köppen-Geiger climate classification maps at 1-km resolution. Sci Data 5, 180214. Available via DIALOG. https://doi.org/10.1038/sdata.2018.214.

Chafe Z, Brauer M, Héroux M-E, Klimont Z, Lanki T, Salonen R, Smith K (2015). Residential heating with wood and coal: health impacts and policy options in Europe and North America.

Caseiro A, Bauer H, Schmidl C, Pio C, Puxbaum H (2009) Wood burning impact on PM $_{10}$ in three Austrian regions. Atmospheric Environment 43(13). p.2186-2195.

CEIP - EMEP Inventory files NFR for Croatia (2019). Available via DIALOG. https://www.ceip.at/ms/ceip_home1/ceip_home/status_reporting/2019_submissions/.

Chen L-A, Watson J, Chow J, Green M, Inouye D, Dick K (2012) Wintertime particulate pollution episodes in an urban valley of the Western US: a case study. Atmospheric Chemistry and Physics 12(21). p.10051-64. doi:10.5194/acp-12-10051-2012

Cincinelli A et al. (2019) Residential wood combustion and its impact on urban air quality in Europe. Current Opinion in Environmental Science \& Health 8. p.10-14. ISSN: 2468-5844. Available via DIALOG. https://doi.org/10.1016/j.coesh.2018.12.007.

Commission Regulation 2015/1185, OJ EU L 193, 21.07.2015

Commission Regulation 2015/1189, OJ EU L 193, 21.07.2015

Crilley LR et al. (2015) Sources and contributions of wood smoke during winter in London. Atmospheric Chemistry and Physics 15. p.3149-3171

Department for Environment, Food \& Rural Affairs (DEFRA) (2019) Clean air strategy 2019. Ref: PB14554. Available via DIALOG. https://www.gov.uk/government/publications/clean-air-strategy-2019.

Deutsche Umwelthilfe (DUH) (2016) Clean heat - Residential wood burning Environmental impact and sustainable solutions. Environmental Action Germany. Available via DIALOG. https://www.cleanheat.eu/en/actions/info-material.html.

Directive 2009/125/EC of the European Parliament and of the Council of 21 October 2009

Directive (EU) 2016/2284 of the European Parliament and of the Council on the reduction of national emissions of certain atmospheric pollutants

Doctors and Scientists Against Wood Smoke Pollution (2019) Particulate Matter and Air Pollution. Available via DIALOG. https://woodsmokepollution.org/particulate-pollution.html.

Doctors and Scientists Against Wood Smoke Pollution (2019) Wood Burning Is a Major Source of Particulate Pollution. Particulate Pollution and Health. Available via DIALOG. https://woodsmokepollution.org/woodsmoke-is-pm.html.

European Biomass Industry Association (EUBIA) (2020) Environmental benefits of biomass. Available via DIALOG. https:/www.eubia.org/cms/wiki-biomass/employment-potential-in-figures/environmental-benefits/.

European Commission (2019) The First Clean Air Outlook, COM(2018) 446 final. p.2

European Commission (2010) Europe 2020 A strategy for smart, sustainable and inclusive growth. COM(2010) 2020

European Commission (2003) Directive 2003/87/EC of the European Parliament and of the Council of 13 October 2003. Off J Eur Union 275:32-46, 25/10/2003, (Annex IV, p. 44)

European Environment Agency (2016) EMEP/EEA air pollutant emission inventory guidebook 2016. Technical guidance to prepare national emission inventories. 1.A.4. Small combustion. ISBN 978-92-9213-8066. doi:10.2800/247535

Hellen H, Hakola H, Haaparanta S, Pietarila H, Kauhaniemi M (2008) Influence of residential wood combustion on local air quality. Science of the total environment 393(2-3). p.283-290.

Herich $\mathrm{H}$ et al. (2014) Overview of the impact of wood burning emissions on carbonaceous aerosols and PM in large parts of the Alpine region. Atmospheric Environment 89. p.64-75 
International Energy Agency (IEA) (2013) Nordic energy technology perspectives: pathways to a carbon neutral energy future. Paris: International Energy Agency. Available via DIALOG. http://energioresund.org/pic_m/23_verdi_182_Nordic-Energy-Technology-Perspectives.pdf.

IPPC (2006) Chapter 2: Stationary combustion. IPCC Guidelines for National Greenhouse Gas Inventories, Prepared by the National Greenhouse Gas Inventories Programme, vol 2. IGES, Japan

Kyprianou I, Serghides D, Varo A, Gouveia JP, Kopeva D, Murauskaite L (2019) Energy poverty policies and measures in 5 EU countries: A comparative study. Energy and Buildings. 196. p.46-60.

Leturcq P (2014) Wood preservation (carbon sequestration) or wood burning (fossil-fuel substitution), which is better for mitigating climate change? Annals of Forest Science, Springer Verlag/EDP Sciences, 2014, 71 (2), pp.117-124. 10.1007/s13595-013-0269-9. hal-01098394

Levander T, Bodin S (2014) Controlling emissions from wood burning: legislation and regulations in Nordic countries to control emissions from residential wood burning - an examination of past experience. Copenhagen: Nordic Council of Ministers

Ministry of Environment and Energy (2019) Republic of Croatia 2019 Informative Inventory Report (19902017) (IIR 2019). Zagreb p.36, 48-50, 70-72, 119-121

Ministry of Environment and Energy (2018) Portal of spatial emission distribution. Available via DIALOG. https://emep.haop.hr/.

Naeher LP, Brauer M, Lipsett M, Zelikoff JT, Simpson CD, Koenig JQ et al. (2007) Woodsmoke health effects: a review. Inhalation Toxicology 19(1). p.67-106

Ofgem (2014) About the Domestic Renewable Heat Incentive. London: Office of Gas and Electricity Markets. Available via DIALOG. https://www.ofgem.gov.uk/environmental-programmes/domestic-rhi/about-domesticrhi.

Pascal M et al. (2013) Assessing the public health impacts of urban air pollution in 25 European cities: Results of the Aphekom project. Science of the Total Environment. p.390-400.

Regulation determining zones and agglomerations according to levels of air pollution on Croatian territory. In Official Gazette 1/2014-24. Available via DIALOG. https://narodnenovine.nn.hr/clanci/sluzbeni/2014_01_1_24.html.

Saarikoski S, Sillanpaeae M, Saarnio K, Hillamo R, Pennanen A, Salonen R (2008) Impact of biomass combustion on urban fine particulate matter in Central and Northern Europe. Water Air and Soil Pollution. 191(14). p.265-277. 10.1007/s11270-008-9623-1

Saarnio K, Niemi JV, Saarikoski S, Aurela M, Timonen H, Teinilä K et al. (2012) Using monosaccharide anhydrides to estimate the impact of wood combustion on fine particles in the Helsinki Metropolitan Area. Boreal Environment Research 17(3-4). p.163-183

Saffari A, Daher N, Samara C, Voutsa D, Kouras A et al. (2013) Increased biomass burning due to the economic crisis in Greece and its adverse impact on wintertime air quality in Thessaloniki. Environmental Science \& Technology 47. p.13313-13320.

United States Environmental Protection Agency (USEPA) (2018) Health and Environmental Effects of Particulate Matter (PM). Available via DIALOG. https://www.epa.gov/pm-pollution/health-and-environmentaleffects-particulate-matter-pm.

World Bioenergy Association (WBA) (2012) The Carbon Neutrality of Biomass from forests. Available via DIALOG. https://worldbioenergy.org/uploads/Factsheet\%20-\%20Carbon\%20neutrality.pdf.

World Health Organisation (WHO) (2018) Ambient (outdoor) air quality and health. Available via DIALOG. https://www.who.int/news-room/fact-sheets/detail/ambient-(outdoor)-air-quality-and-health.

World Health Organisation (WHO) (2014) 7 million premature deaths annually linked to air pollution. Available via DIALOG. http://www.who.int/mediacentre/news/releases/2014/air-pollution/en/.

World Health Organisation (WHO) (2013) Health effects of particulate matter. Policy implications for countries in eastern Europe, Caucasus and central Asia. Available via DIALOG. http://www.euro.who.int/_data/assets/pdf_file/0006/189051/Health-effects-of-particulate-matter-final-Eng.pdf. 